Berezovskyi, A. V., \& Hurova, T. O. (2005). Problemy pasovyshchnoho sezonu. Vet medytsyna Ukrainy, 6, 39-40

Horalskyi, L. P., Khomych, V. T., \& Kononskyi, O. I. (2005). Osnovy histolohichnoi tekhniky i morfofunktsionalni metody doslidzhennia u normi ta pry patolohii. Zhytomyr: DAEU.

Skrypka, M. V., Yatsenko, I. V., \& Panikar, I. I. (2018). Osnovy sudovo-veterynarnoi ekspertyzy trupiv ta zhyvykh tvaryn. Odesa.

Zon, H. A. (2002). Sudovo-veterynarna ekspertyza. Sumy.

Zon, H. A., Skrypka, M. V., \& Ivanivska, L. B 2009. Patolohoanatomichnyi roztyn tvaryn: Navchalnyi posibnyk. Donetsk.

Meyer. (2016). Class Lecture. Animal Nutrition. University of Missouri-Columbia, MO. 16 September.

William, O. Reece. (2009). Functional Anatomy and Physiology of Domestic Animals, WILEY-BLACKWELL.

William O. Reece, Howard H. Erickson, Jesse P. Goff, \& Etsuro E. Uemura. (2015). Dukes' Physiology of Domestic Animals. John Wiley \& Sons.

Rowen D. Frandson, W. Lee Wilke, Anna Dee Fails. (2009). Anatomy and Physiology of Farm Animals. John Wiley \& Sons.

\title{
QUALITY CONTROL AND SAFETY OF MEAT RAW FOR USE OF EXPRESS METHOD
}

\author{
N. M. Bogatko', I. V. Yatsenko², L. R. Rutina ${ }^{2}$ \\ ${ }^{1}$ BilaTserkva National Agrarian University, Ukraine \\ E-mail: nadivabogatko@ukr.net \\ ${ }^{2}$ Kharkiv State Zooveterinary Academy, Kharkiv, Ukraine \\ Academichna str., 1, Mala Danylivka, Dergachi district, Kharkiv region, Ukraine, 62341 \\ E-mail: yacenko-1971@ukr.net
}

\begin{abstract}
Effective food quality control and quality control systems are essential for protecting the health of consumers. They are necessary to create conditions in which the state can guarantee the safety and quality of meat raw material entering into the implementation, check compliance with its national requirements. Domestic meat processing enterprises are strategically important in the context of ensuring Ukraine's security in relation to food. Meat products are irreplaceable in the human diet and their consumption affects the health of the population. In the countries of the European Community, considerable attention is paid to the improvement of the legis/ative framework for controlling the traceability of meat raw material throughout the entire food chain - from field to table.

Market operators are required to ensure the introduction of procedures for the withdrawal of meat products that poses a potential risk to consumers' health and to keep the suppliers of raw materials properly accounted for in order to identify the source of the problem.

Particularly topical issues are state control of livestock products in modern conditions in connection with the development of the agro-industrial complex of Ukraine. One of the requirements for the prevention of the implementation of hazardous and poor-quality meat raw materials is the complex control system taking in to account commonly accepted and developed new express methods for determining the degree of freshness of meat raw material coming from the power for food production or sold in the trading network.

The research establishes the degree of freshness of meat raw material obtained from various types of slaughtered animals by conventional methods and an express photometric method using the Nessler
\end{abstract}

reagent, based on the determination of the optical density of the intensity of the coloration of meat and water extraction due to the accumulation of ammonia and ammonium salts in meat, which reacts with Nessler's reagent to form a compound from olive-yellow to yellow-orange.

The degree of freshness of meat raw material according to generally accepted methods is established. It was determined that the highest optical density of fresh and doubtful freshness of minced meat was in the meat raw material of the horse $-1,302 \pm 0,004$ and $1,413 \pm 0,005 \mathrm{~B}$; from beef, respectively 1,262 \pm 0,001 and $1,320 \pm 0,007 \mathrm{~B}$, from veal, respectively, $1,253 \pm 0,003$ and $1,287 \pm 0,003 B$, respectively, and the lowest according to the degree of freshness - in the minced meat from urkey meat $-0,504 \pm 0,001 B$ and $0,695 \pm 0,005 B$; in the meat of chicken (breast fillet) respectively, $0,572 \pm 0,001$ and $0,770 \pm 0,013 \mathrm{~B}$; in the broiler chicken fillet ("Nasha Ryaba") - respectively $0,604 \pm 0,001$ and $0,805 \pm 0,004 B$. It was determined that the highest optical density from extraction of fresh and doubtful freshness of meat minced meat was in the minced meat "Chicken", respectively, 1,109 $\pm 0,001$ and 1,331 $\pm 0,050 \mathrm{~B}$; "Kotletnoy" respectively - 0,947 $\pm 0,001$ and 1,213 $\pm 0,003 \mathrm{~B}$, and the lowest, respectively, in minced meat "Home" - 0,822 $\pm 0,001$ and 1,003 $\pm 0,006$ $B$ respectively.

Patented express photometric method for determining the degree of freshness of meat raw material, which has a reliability in the test of $99.9 \%$, should be used in conjunction with other generally accepted methods for determining the quality and safety of this meat raw material.

Key words: quality, safety, meat raw material, express photometric method, degree of freshness. 


\title{
КОНТРОЛЬ ЯКОСТІ ТА БЕЗПЕЧНОСТІ М'ЯСНОЇ СИРОВИНИ ЗА ЗАСТОСУВАННЯ ЕКСПРЕСНОГО МЕТОДУ
}

\author{
Н. М. Богатко1, І. В. Яценко², Л. Р. Рютіна², \\ ${ }^{1}$ Білоцерківський національний аграрний університет, Україна \\ E-mail: nadiyabogatko@ukr.net \\ ${ }^{2}$ Харківська державна зооветеринарна академія, Харків, Україна \\ вул. Академічна, 1, смт. Мала Данилівка, Дергачівський район, \\ Харківська обл., 62341 \\ E-mail: vacenko-1971@ukr.net
}

\begin{abstract}
Дослідженнями встановлено ступінь свіжості м'ясної сировини, отриманої від різних видів забійних тварин загальноприйнятими методами та експресним фотометричним методом із застосуванням реактиву Неслера, який грунтується на визначенні оптичної густини інтенсивності забарвлення м'ясо-водної витяжки внаслідок накопичення в м'ясі аміаку та солей амонію, який реагує із реактивом Неслера, утворюючи сполуку від оливково-жовтого до жовто-помаранчевий кольору.

Встановлено ступінь свіжості м'ясної сировини за загальноприйнятими методами. Визначено, що найвища оптична густина свіжого та сумнівної свіжості м'ясного фрариу становила у м'ясній сировині із

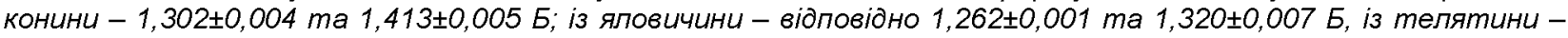

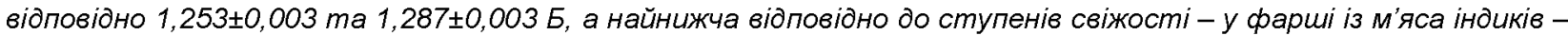

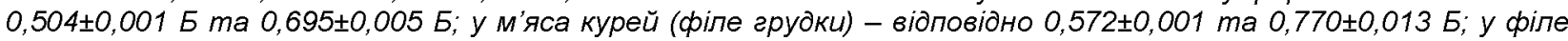

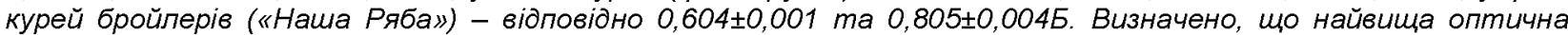
густина із витяжки свіжого та сумнівної свіжості м'ясного фрариу становила у фрариі «Курячому» відповідно -

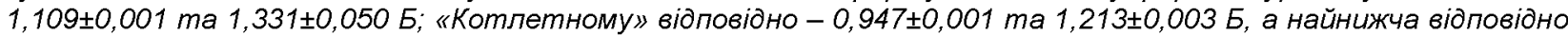

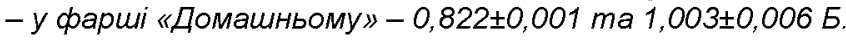

Запатентований експресний фотометричний метод визначення ступеня свіжості м'ясної сировини, який має достовірність у випробуванні у 99,9 \%, необхідно використовувати в комплексі з інилми загальноприйнятими методами для встановлення якості та безпечності даної м'ясної сировини.
\end{abstract}

Ключові слова: якість, безпечність, м'ясна сировина, експресний фотометричний метод, ступінь свіжості

\section{Вступ}

Актуальність теми. Ефективні системи контролю якості та безпечності харчових продуктів мають важливе значення для захисту здоров'я споживачів. Вони необхідні для створення умов, у яких держава може гарантувати безпечність і якість м'ясної сировини, що надходить у реалізацію, перевіряти відповідність ії національним вимогам (Bogatko, Bukalova, Sakhnyuk, \& Bumblebee, 2016). Вітчизняні підприємства м'ясопереробної галузі $\epsilon$ стратегічно важливими у контексті забезпечення безпеки України відносно продуктів харчування.

Аналіз останніх досліджень. М'ясні продукти $€$ незамінними у раціоні людини та споживання їх впливає на здоров'я населення (Gvozdinskaya, 2017; Chernorotov, 2016). у країнах Європейської Співдружності значну увагу приділяють удосконаленню законодавчої бази щодо контролю простежуваності м'ясної сировини на всьому харчовому ланцюгу - від поля до столу (Bogatko, 2017).

Згідно з вимогами Регламенту ЄС 178/2002 оператори ринку, які займаються виробництвом та обігом м'ясної сировини, зобов'язані забезпечувати впровадження процедур щодо відкликання м'ясної сировини, яка становить потенційний ризик для здоров'я споживачів, і вести належний облік постачальників сировини, щоб можна було виявити джерело проблеми (Regulation (EC) No 178/2002). Особливо актуальні питання державного контролю продукції тваринництва в сучасних умовах у зв'язку з розвитком агропромислового комплексу України (Zasekin, 2011). Однією з вимог недопущення у реалізацію небезпечної та неякісної м'ясної сировини $є$ комплексна система контролю 3 урахуванням загальноприйнятих та розроблених нових експресних методів визначення ступеня свіжості м'ясної сировини, яка надходить на потужності для виробництва харчових продуктів або реалізується у торгівельній мережі (Bogatko, Yatsenko, Dudus, \& Bukalova, 2017; Desker, \& Xu, 2009).

Mema і завдання досліджень. Мета роботи встановити якість та безпечність різних видів м'ясної сировини за ступенем свіжості.

Завдання дослідження: встановити достовірність експресного фотометричного методу визначення ступеня свіжості м'ясної сировини із застосуванням реактиву Неслера та проаналізувати ступінь свіжості даної м'ясної сировини за загальноприйнятими методами.

\section{Матеріал та методи дослідження}

Дослідження проводили на відібраних пробах м'ясної сировини у кількості 200 г, отриманої від різних видів забійних тварин, на потужностях з виробництва та зберігання м'яса та м'ясопродуктів (оптових базах) та при реалізації у торгівельній мережі та на агропромислових ринках Київської, Миколаївської, Харківської областей.

Проби м'ясної сировини були попередньо досліджені загальноприйнятими методами на встановлення ступеня свіжості згідно з ГОСТ 23392-2016: визначення продуктів первинного розпаду білків в бульйоні; визначення летких жирних кислот; визначення кількості мікроорганізмів (GOST 23392-2016). За ветеринарними методами визначали величину $\mathrm{pH}$ м'ясо-водної витяжки; вміст аміно-аміачного азоту, сірководню, аміаку (Bogatko et al., 2012).

Для встановлення ступеня свіжості м'ясної сировини нами був розроблений експресний фотометричний метод із застосуванням реактиву Неслера (Method Of Determining, 2018). Експресний 
фотометричний метод визначення ступеня свіжості м'ясної сировини полягає у використанні профрільтрованої м'ясо-водної витяжки у співвідношенні $1: 2$ у кількості $3,0-3,1 \mathrm{~cm}^{3} \quad 3$ додаванням 1,0-1,1 $\mathrm{cm}^{3}$ реактиву Неслера за витримування упродовж 4-5 хвилин та подальшим центрифугуванням упродовж 10-11 хвилин за 1000 об/хв та вимірюванням оптичної густини інтенсивності забарвлення у Белах (Б) у кюветі з товщиною поглинаючого світла $1,0 \mathrm{~cm}$ на фоотометрі

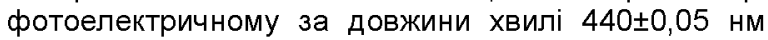
(синій світофрільтр) при використанні в якості контрольної проби дистильованої води для встановленні якості та безпечності м'ясної сировини, отриманої від різних видів м'яса забійних тварин. Розроблений експресний метод ґрунтується на визначенні оптичної густини інтенсивності забарвлення м'ясо-водної витяжки внаслідок накопичення в м'ясі аміаку та солей амонію, який реагує із реактивом Неслера утворюючи сполуку від оливково-жовтого до жовто-помаранчевий кольору. Для встановлення оптичної густини інтенсивності забарвлення м'ясо-водної витяжки 3 реактивом Неслера нами були проведені експериментальні дослідження сумнівної свіжості і несвіжої м'ясної сировини.

Результати та їх обговорення
В Україні існують методи контролювання якості та безпечності м'ясної сировини, які регламентуються чинними нормативними документами та «Правилами передзабійного ветеринарного огляду тварин та ветеринарносанітарної експертизи м'яса і м'ясних продуктів» (2002p.). У нормативно-правовому європейському акті Директиві Ради ЄC 94/65, яка встановлюе вимоги, застосовані до виробництва та розміщення на ринку січеного м'яса і м'ясних виробів, вказується здійснення належного контролю санітарно-гігієнічних умов щодо виробництва, зберігання та реалізації м'ясної сировини на підприємствах.

Важливим показником якості та безпечності м'яса забійних тварин є встановлення його свіжості за його виробництва, зберігання та реалізації. За дотримання санітарно-гігієнічних вимог необхідно контролювати відносну вологість повітря та температурні режими під час зберігання та реалізації м'ясної сировини, виготовлених із різних видів забійних тварин відповідно до вимог чинних нормативних документів.

Було досліджено м'ясну сировину, отриману від різних видів забійних тварин, на встановлення ступеня свіжості загальноприйнятими методами. У таблицях 1, 2, 3 представлені дані за нашими дослідженнями щодо встановлення показників свіжого ступеня свіжості, сумнівної свіжості і несвіжої м'ясної сировини.

Таблиця 1

Показники свіжого ступеня свіжості м'ясної сировини за загальноприйнятими методами та розробленим експресним фотометричним методом, отриманої від різних видів забійних тварин, $\mathrm{M} \pm \mathrm{n}, \mathrm{n}=100$

\begin{tabular}{|c|c|c|c|c|c|c|}
\hline \multirow[b]{2}{*}{$\begin{array}{l}\text { No } \\
3 / \pi\end{array}$} & \multirow[b]{2}{*}{$\begin{array}{c}\text { Вид досліджуваної } \\
\text { м'ясної сировини, } \Pi=5\end{array}$} & \multicolumn{5}{|c|}{ Загальноприйняті методи } \\
\hline & & $\begin{array}{l}\text { Мікроскопія } \\
\text { мазків- } \\
\text { відбитків }\end{array}$ & $\begin{array}{l}\text { Якісна реакція з } \\
\text { міді сульфату }\end{array}$ & 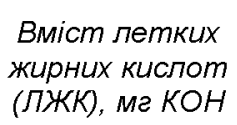 & $\begin{array}{l}\text { Вміст аміно- } \\
\text { аміачного } \\
\text { азоту, ме }\end{array}$ & Величина $\mathrm{pH}$ \\
\hline 1 & 2 & 3 & 4 & 5 & 6 & 7 \\
\hline 1 & $\begin{array}{l}\text { Фарш зі свинини } \\
\text { нежирної }\end{array}$ & $6 \pm 1$ & + & $2,01 \pm 0,06$ & $0,98 \pm 0,04$ & $5,90 \pm 0,03$ \\
\hline 2 & $\begin{array}{l}\text { Фарш зі свинини } \\
\text { жирної }\end{array}$ & $7 \pm 1$ & + & $2,95 \pm 0,09$ & $0,94 \pm 0,06$ & $5,86 \pm 0,02$ \\
\hline 3 & Фарш з яловичини & $6 \pm 1$ & + & $2,03 \pm 0,05$ & $1,08 \pm 0,04$ & $5,92 \pm 0,03$ \\
\hline 4 & Фарш із телятини & $4 \pm 2$ & + & $2,17 \pm 0,07$ & $0,95 \pm 0,07$ & $5,89 \pm 0,02$ \\
\hline 5 & Фарш із баранини & $7 \pm 1$ & + & $2,18 \pm 0,06$ & $0,94 \pm 0,06$ & $5,81 \pm 0,02$ \\
\hline 6 & Фарш із конини & $6 \pm 1$ & + & $2,54 \pm 0,10$ & $1,13 \pm 0,08$ & $5,82 \pm 0,02$ \\
\hline 7 & Фарш із крільчатини & $5 \pm 1$ & + & $1,98 \pm 0,04$ & $1,26 \pm 0,05$ & $5,91 \pm 0,02$ \\
\hline 8 & Фарш із фріле індиків & $6 \pm 1$ & + & $2,19 \pm 0,03$ & $1,05 \pm 0,06$ & $5,70 \pm 0,03$ \\
\hline 9 & $\begin{array}{l}\text { Фарш зі стегенців } \\
\text { свійської курки }\end{array}$ & $5 \pm 2$ & + & $1,81 \pm 0,02$ & $1,03 \pm 0,04$ & $5,88 \pm 0,02$ \\
\hline 10 & $\begin{array}{l}\text { Фарш із фріле } \\
\text { свійської курки }\end{array}$ & $6 \pm 1$ & + & $1,91 \pm 0,04$ & $0,89 \pm 0,03$ & $5,83 \pm 0,03$ \\
\hline 11 & $\begin{array}{l}\text { Фарш із філе курей } \\
\text { («Наша Ряба») }\end{array}$ & $9 \pm 1$ & + & $2,11 \pm 0,04$ & $0,93 \pm 0,04$ & $5,93 \pm 0,02$ \\
\hline
\end{tabular}


ВЕТЕРИНАРІЯ, ТЕХНОЛОГІЇ ТВАРИННИЦТВА ТА ПРИРОДОКОРИСТУВАННЯ, 2018, №2 Науково-практичний журнал Харківської державної зооветеринарної академії

\begin{tabular}{|c|c|c|c|c|c|c|}
\hline 12 & $\begin{array}{l}\text { Фарш із м'яса } \\
\text { перепілок }\end{array}$ & $7 \pm 1$ & + & $1,72 \pm 0,03$ & $0,98 \pm 0,05$ & $5,96 \pm 0,02$ \\
\hline 13 & Фарш із м'яса гусей & $7 \pm 1$ & + & $3,73 \pm 0,07$ & $1,04 \pm 0,07$ & $5,87 \pm 0,02$ \\
\hline 14 & $\begin{array}{l}\text { Фарш із м'яса качок } \\
\text { свійських }\end{array}$ & $6 \pm 1$ & + & $3,49 \pm 0,05$ & $1,12 \pm 0,06$ & $5,91 \pm 0,02$ \\
\hline 15 & $\begin{array}{l}\text { Фарш із м'яса качок } \\
\text { мулард }\end{array}$ & $6 \pm 1$ & + & $3,18 \pm 0,04$ & $1,08 \pm 0,04$ & $5,80 \pm 0,03$ \\
\hline 16 & $\begin{array}{l}\text { Фарш м'ясний із } \\
\text { свинини } \\
\text { заморожений }\end{array}$ & $9 \pm 1$ & + & $3,02 \pm 0,08$ & $1,07 \pm 0,05$ & $5,82 \pm 0,02$ \\
\hline 17 & $\begin{array}{l}\text { Фарш «Домашний» } \\
\text { із свинини та } \\
\text { яловичини }\end{array}$ & $9 \pm 1$ & + & $2,01 \pm 0,06$ & $0,94 \pm 0,07$ & $5,95 \pm 0,02$ \\
\hline 18 & $\begin{array}{l}\text { Фарш «Котлетний» } \\
\text { із свинини та } \\
\text { яловичини з } \\
\text { додаванням сала, } \\
\mathrm{n}=5\end{array}$ & $8 \pm 1$ & + & $2,78 \pm 0,08$ & $0,99 \pm 0,05$ & $5,87 \pm 0,03$ \\
\hline 19 & $\begin{array}{l}\text { Фарш } \\
\text { «Напівжирний» із } \\
\text { свинини з } \\
\text { додаванням сала }\end{array}$ & $9 \pm 1$ & + & $2,77 \pm 0,05$ & $1,13 \pm 0,08$ & $6,11 \pm 0,03$ \\
\hline 20 & Фарш «Курячий» & $11 \pm 1$ & \pm & $2,23 \pm 0,03$ & $0,78 \pm 0,03$ & $6,03 \pm 0,02$ \\
\hline
\end{tabular}

Аналізуючи дані таблиці 1, необхідно відмітити, що м'ясна сировина за загальноприйнятими методами та розробленим експресним фотометричним методом (табл. 4, 5) відповідала свіжому ступеню, крім фаршу «Курячого», що реалізувався у торгівельній мережікількість мікроорганізмів перевищували нормативи і становила $11 \pm 1$ та реакція з міді сульфатом була сумнівної свіжості. За дослідження визначення вмісту сірководню та аміаку - відмічалася негативна реакція у всіх досліджуваних пробам м'ясної сировини, крім фаршу «Курячого», у якому відмічалася сумнівна реакція.

При проведенні експериментальних досліджень було встановлено сумнівну ступінь свіжості м'ясної сировини за загальноприйнятими і розробленим експресним фотометричним методами.

Необхідно відмітити, що показники м'ясної сировини за загальноприйнятими методами відповідали відповідній ступені свіжості. Результати досліджень представлені у таблицях 2, 3.

Таблиця 2

Показники сумнівної свіжості м'ясної сировини за загальноприйнятими методами та розробленим експресним фотометричним методом, отриманої від різних видів забійних тварин, M \pm n, n=100

\begin{tabular}{|c|c|c|c|c|c|c|}
\hline \multirow[b]{2}{*}{$\begin{array}{l}\text { № } \\
3 / \pi\end{array}$} & \multirow[b]{2}{*}{$\begin{array}{c}\text { Вид досліджуваної } \\
\text { м'ясної сировини, } n=5\end{array}$} & \multicolumn{5}{|c|}{ Загальноприйняті методи } \\
\hline & & $\begin{array}{c}\text { Мікроскопія } \\
\text { мазків-відбитків }\end{array}$ & $\begin{array}{l}\text { Якісна реакція } 3 \\
\text { міді сульфату }\end{array}$ & 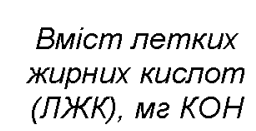 & $\begin{array}{l}\text { Вміст аміно- } \\
\text { аміачного } \\
\text { азоту, ме }\end{array}$ & Велччина рН \\
\hline 1 & 2 & 3 & 4 & 5 & 6 & 7 \\
\hline 1 & $\begin{array}{l}\text { Фарш зі свинини } \\
\text { нежирної }\end{array}$ & $12 \pm 1$ & \pm & $4,84 \pm 0,06$ & $1,34 \pm 0,05$ & $5,61 \pm 0,01$ \\
\hline 2 & $\begin{array}{l}\text { Фарш зі свинини } \\
\text { жирної }\end{array}$ & $14 \pm 2$ & \pm & $4,47 \pm 0,11$ & $1,43 \pm 0,06$ & $5,55 \pm 0,02$ \\
\hline 3 & Фарш з яловичини & $13 \pm 2$ & \pm & $4,12 \pm 0,07$ & $1,44 \pm 0,05$ & $5,64 \pm 0,03$ \\
\hline 4 & Фарш із телятини & $14 \pm 2$ & \pm & $4,14 \pm 0,08$ & $1,39 \pm 0,04$ & $5,68 \pm 0,02$ \\
\hline 5 & Фарш із баранини & $13 \pm 2$ & \pm & $4,31 \pm 0,09$ & $1,38 \pm 0,06$ & $5,72 \pm 0,02$ \\
\hline 6 & Фарш із конини & $16 \pm 2$ & \pm & $4,72 \pm 0,11$ & $1,49 \pm 0,07$ & $5,67 \pm 0,02$ \\
\hline 7 & Фарш із крільчатини & $14 \pm 2$ & \pm & $4,23 \pm 0,08$ & $2,16 \pm 0,06$ & $5,62 \pm 0,02$ \\
\hline 8 & Фарш із філе індиків & $13 \pm 2$ & \pm & $4,21 \pm 0,09$ & $1,42 \pm 0,04$ & $5,66 \pm 0,03$ \\
\hline
\end{tabular}


ВЕТЕРИНАРІЯ, ТЕХНОЛОГІЇ ТВАРИННИЦТВА ТА ПРИРОДОКОРИСТУВАННЯ, 2018, №2 Науково-практичний журнал Харківської державної зооветеринарної академії

\begin{tabular}{|c|c|c|c|c|c|c|}
\hline 9 & $\begin{array}{l}\text { Фарш зі стегенців } \\
\text { свійської курки }\end{array}$ & $14 \pm 2$ & \pm & $5,02 \pm 0,10$ & $1,58 \pm 0,05$ & $5,58 \pm 0,02$ \\
\hline 10 & $\begin{array}{l}\text { Фарш із філе } \\
\text { свійської курки }\end{array}$ & $19 \pm 2$ & \pm & $5,07 \pm 0,08$ & $1,49 \pm 0,04$ & $5,53 \pm 0,03$ \\
\hline 11 & $\begin{array}{l}\text { Фарш із філе курей } \\
\text { («Наша Ряба»), n=5 }\end{array}$ & $20 \pm 2$ & \pm & $4,23 \pm 0,07$ & $1,39 \pm 0,06$ & $6,22 \pm 0,02$ \\
\hline 12 & $\begin{array}{l}\text { Фарш із м'яса } \\
\text { перепілок, n=5 }\end{array}$ & $18 \pm 1$ & \pm & $4,73 \pm 0,09$ & $1,33 \pm 0,04$ & $5,56 \pm 0,02$ \\
\hline 13 & $\begin{array}{l}\text { Фарш із м'яса гусей, } \\
n=5\end{array}$ & $14 \pm 1$ & \pm & $3,74 \pm 0,08$ & $1,30 \pm 0,07$ & $6,35 \pm 0,02$ \\
\hline 14 & $\begin{array}{l}\text { Фарш із м'яса качок } \\
\text { свійських }\end{array}$ & $16 \pm 2$ & \pm & $5,43 \pm 0,12$ & $1,45 \pm 0,05$ & $6,37 \pm 0,02$ \\
\hline 15 & $\begin{array}{l}\text { Фарш із м'яса качок } \\
\text { мулард }\end{array}$ & $13 \pm 2$ & \pm & $5,25 \pm 0,14$ & $1,36 \pm 0,04$ & $6,33 \pm 0,03$ \\
\hline 16 & $\begin{array}{l}\text { Фарш м'ясний із } \\
\text { свинини } \\
\text { заморожений }\end{array}$ & $22 \pm 2$ & \pm & $5,01 \pm 0,12$ & $1,37 \pm 0,06$ & $5,53 \pm 0,02$ \\
\hline 17 & $\begin{array}{l}\text { Фарш «Домашній» із } \\
\text { свинини та } \\
\text { яловичини }\end{array}$ & $21 \pm 3$ & \pm & $4,62 \pm 0,08$ & $1,46 \pm 0,06$ & $5,57 \pm 0,02$ \\
\hline 18 & $\begin{array}{l}\text { Фарш «Котлетний» } \\
\text { із свинини та } \\
\text { яловичини } 3 \\
\text { додаванням сала }\end{array}$ & $20 \pm 3$ & \pm & $5,27 \pm 0,12$ & $1,58 \pm 0,04$ & $5,61 \pm 0,03$ \\
\hline 19 & $\begin{array}{l}\text { Фарш } \\
\text { «Напівжирний» із } \\
\text { свинини з } \\
\text { додаванням сала } \\
\end{array}$ & $19 \pm 2$ & \pm & $5,44 \pm 0,11$ & $1,60 \pm 0,07$ & $5,68 \pm 0,03$ \\
\hline 20 & Фарш «Курячий» & $15 \pm 2$ & \pm & $4,56 \pm 0,09$ & $1,33 \pm 0,04$ & $6,42 \pm 0,02$ \\
\hline
\end{tabular}

Аналізуючи дані таблиці 2, необхідно відмітити, що м'ясна сировина за загальноприйнятими методами та розробленим експресним фотометричним методом (табл. 4,5$)$ відповідала сумнівному ступеню свіжості.

Таблиця 3

Показники несвіжої м'ясної сировини за загальноприйнятими методами та розробленим експресним фотометричним методом, отриманої від різних видів забійних тварин, $\mathrm{M} \pm \mathrm{n}, \mathrm{n}=100$

\begin{tabular}{|c|c|c|c|c|c|c|}
\hline \multirow[b]{2}{*}{$\begin{array}{l}\text { № } \\
3 / \Pi\end{array}$} & \multirow[b]{2}{*}{$\begin{array}{c}\text { Вид досліджуваної } \\
\text { м'ясної сировини, } \\
n=5\end{array}$} & \multicolumn{5}{|c|}{ Загальноприйняті методи } \\
\hline & & $\begin{array}{c}\text { Мікроскопія } \\
\text { мазків- } \\
\text { відбитків }\end{array}$ & $\begin{array}{l}\text { Якісна реакція з } \\
\text { міді сульфрату }\end{array}$ & 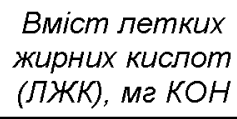 & $\begin{array}{l}\text { Вміст аміно- } \\
\text { аміачного } \\
\text { азоту, ме }\end{array}$ & $\begin{array}{c}\text { Величина } \\
\text { рH }\end{array}$ \\
\hline 1 & 2 & 3 & 4 & 5 & 6 & 7 \\
\hline 1 & $\begin{array}{l}\text { Фарш зі свинини } \\
\text { нежирної }\end{array}$ & $45 \pm 5$ & - & $9,26 \pm 0,81$ & $1,77 \pm 0,08$ & $5,51 \pm 0,03$ \\
\hline 2 & Фарш зі свинини жирної & $38 \pm 4$ & - & $9,42 \pm 0,73$ & $1,90 \pm 0,11$ & $5,50 \pm 0,02$ \\
\hline 3 & Фарш з яловичини & $44 \pm 4$ & - & $9,34 \pm 0,54$ & $1,88 \pm 0,09$ & $5,57 \pm 0,03$ \\
\hline 4 & Фарш із телятини & $43 \pm 6$ & - & $9,33 \pm 0,58$ & $2,13 \pm 0,10$ & $5,58 \pm 0,02$ \\
\hline 5 & Фарш із баранини & $39 \pm 4$ & - & $9,43 \pm 0,57$ & $2,09 \pm 0,12$ & $5,61 \pm 0,02$ \\
\hline 6 & Фарш із конини & $38 \pm 5$ & - & $9,85 \pm 0,74$ & $2,25 \pm 0,13$ & $5,54 \pm 0,02$ \\
\hline 7 & Фарш із крільчатини & $37 \pm 4$ & - & $9,31 \pm 0,68$ & $2,95 \pm 0,11$ & $5,51 \pm 0,02$ \\
\hline 8 & Фарш із філе індиків & $38 \pm 5$ & - & $9,47 \pm 0,62$ & $2,06 \pm 0,07$ & $5,52 \pm 0,03$ \\
\hline 9 & $\begin{array}{l}\text { Фарш зі стегенців } \\
\text { свійської курки }\end{array}$ & $50 \pm 6$ & - & $9,81 \pm 0,65$ & $2,02 \pm 0,09$ & $5,52 \pm 0,02$ \\
\hline 10 & $\begin{array}{l}\text { Фарш із філе свійської } \\
\text { курки, } n=5\end{array}$ & $49 \pm 6$ & - & $9,79 \pm 0,74$ & $2,14 \pm 0,08$ & $5,50 \pm 0,03$ \\
\hline 11 & Фарш із фріле курей & $54 \pm 7$ & - & $9,55 \pm 0,99$ & $2,40 \pm 0,10$ & $6,59 \pm 0,02$ \\
\hline
\end{tabular}


ВЕТЕРИНАРІЯ, ТЕХНОЛОГІЇ ТВАРИННИЦТВА ТА ПРИРОДОКОРИСТУВАННЯ, 2018, №2 Науково-практичний журнал Харківської державної зооветеринарної академії

\begin{tabular}{|c|l|l|l|l|l|l|}
\hline & («Наша Ряба») & & & & \\
\hline 12 & Фарш із м'яса перепілок & $45 \pm 6$ & - & $9,72 \pm 1,04$ & $2,36 \pm 0,05$ & $5,52 \pm 0,02$ \\
\hline 13 & Фарш із м'яса гусей & $43 \pm 6$ & - & $10,02 \pm 1,09$ & $2,34 \pm 0,07$ & $6,71 \pm 0,02$ \\
\hline 14 & $\begin{array}{l}\text { Фарш із м'яса качок } \\
\text { свійських }\end{array}$ & $39 \pm 5$ & - & $10,06 \pm 1,10$ & $2,51 \pm 0,09$ & $6,63 \pm 0,02$ \\
\hline 15 & $\begin{array}{l}\text { Фарш із м'яса качок } \\
\text { мулард }\end{array}$ & $38 \pm 4$ & - & $10,26 \pm 1,14$ & $2,66 \pm 0,11$ & $6,68 \pm 0,03$ \\
\hline 16 & $\begin{array}{l}\text { Фарш м'ясний із свинини } \\
\text { заморожений }\end{array}$ & $44 \pm 4$ & - & $10,57 \pm 1,13$ & $2,46 \pm 0,15$ & $6,75 \pm 0,02$ \\
\hline 17 & $\begin{array}{l}\text { Фарш «Домашний» із } \\
\text { свинини та яловичини }\end{array}$ & $36 \pm 4$ & - & $10,38 \pm 1,04$ & $2,22 \pm 0,13$ & $6,67 \pm 0,02$ \\
\hline 18 & $\begin{array}{l}\text { Фарш «Котлетний» із } \\
\text { свинини та яловичини з } \\
\text { додаванням сала }\end{array}$ & $48 \pm 5$ & - & $10,17 \pm 1,12$ & $2,43 \pm 0,16$ & $6,69 \pm 0,03$ \\
\hline 19 & $\begin{array}{l}\text { Фарш «Напівжирний» із } \\
\text { свинини з додаванням } \\
\text { сала }\end{array}$ & $51 \pm 6$ & - & $10,45 \pm 0,98$ & $2,68 \pm 0,14$ & $6,68 \pm 0,03$ \\
\hline 20 & Фарш «Курячий» & $57 \pm 5$ & - & $11,25 \pm 1,02$ & $3,23 \pm 0,12$ & $6,66 \pm 0,02$ \\
\hline
\end{tabular}

Аналізуючи дані таблиці 3, необхідно відмітити, що м'ясна сировина за загальноприйнятими методами та розробленим експресним фотометричним методом (табл. 4, 5) відповідала несвіжому ступеню.

Дані досліджувані проби були досліджені також експресним фотометричним методом із застосуванням реактиву Неслера на встановлення та підтвердження ступеня свіжості. Ці досліджувані проби піддавалися випробуванню за розробленим експресним фотометричним методом визначення ступеня свіжості при встановленні оптичної густини за інтенсивністю забарвлення м'ясної витяжки із застосуванням реактиву Неслера.

Використовуючи розроблений експресний фотометричний метод визначення ступеня свіжості м'ясної сировини, ми провели експериментальні дослідження, де визначили оптичну густину інтенсивності забарвлення витяжки із м'ясних фаршів 3 реактивом Неслера за допомогою фотометра електричного різних ступенів свіжості на 100 досліджуваних пробах, виготовлених від різних видів м'яса забійних тварин. Результати досліджень представлені у таблицях 4, 5.

Таблиця 4

Показники оптичної густини інтенсивності забарвлення витяжки 3 м'ясних фаршів 3 реактивом Неслера різних ступеней свіжості фотометричним методом, $\mathrm{M} \pm \mathrm{n}, \mathrm{n=75}$

\begin{tabular}{|c|c|c|c|c|}
\hline \multirow[t]{3}{*}{ № $\Pi / n$} & \multirow{3}{*}{ Вид м'ясної сировини, $n=5$} & \multirow{2}{*}{\multicolumn{3}{|c|}{$\begin{array}{c}\text { Показники оптичної густини інтенсивності забарвлення витяжки } \\
\text { з м'ясних фраршів з реактивом Неслера, у Белах (Б) } \\
\text { Cтупені свіжості м'ясних фрариів }\end{array}$}} \\
\hline & & & & \\
\hline & & $\begin{array}{c}\text { Свіжі } \\
\text { (оливково-жовтий } \\
\text { колір) }\end{array}$ & $\begin{array}{l}\text { сумнівної свіжості } \\
\text { (інтенсивний жовтий } \\
\text { колір) }\end{array}$ & $\begin{array}{c}\text { Несвіжі } \\
\text { (жовто- помаранчевий } \\
\text { колір) }\end{array}$ \\
\hline 1 & Фарш із свинини нежирної & $0,718 \pm 0,002$ & $0,821 \pm 0,002$ & $>0,822$ \\
\hline 2 & Фарш із свинини жирної & $0,667 \pm 0,001$ & $0,705 \pm 0,004$ & $>0,706$ \\
\hline 3 & Фарш із яловичини & $1,262 \pm 0,001$ & $1,320 \pm 0,007$ & $>1,321$ \\
\hline 4 & Фарш із телятини & $1,253 \pm 0,003$ & $1,287 \pm 0,003$ & $>1,288$ \\
\hline 5 & Фарш із баранини & $1,051 \pm 0,001$ & $1,186 \pm 0,001$ & $>1,187$ \\
\hline 6 & Фарш із конини & $1,302 \pm 0,004$ & $1,413 \pm 0,005$ & $>1,414$ \\
\hline 7 & Фарш із м'яса крільчатини & $0,770 \pm 0,001$ & $1,200 \pm 0,005$ & $>1,201$ \\
\hline 8 & Фарш із м'яса фріле індика & $0,504 \pm 0,001$ & $0,695 \pm 0,005$ & $>0,696$ \\
\hline 9 & $\begin{array}{l}\text { Фарш із м'яса курки свійської } \\
\text { (стегно) }\end{array}$ & $0,919 \pm 0,001$ & $1,262 \pm 0,004$ & $>1,263$ \\
\hline 10 & $\begin{array}{l}\text { Фарш із м'яса курки свійської (фріле } \\
\text { грудки) }\end{array}$ & $0,572 \pm 0,001$ & $0,770 \pm 0,013$ & $>0,771$ \\
\hline 11 & $\begin{array}{l}\text { Фарш із філе курей бройлерів } \\
\text { «Наша Ряба» }\end{array}$ & $0,604 \pm 0,001$ & $0,805 \pm 0,004$ & $>0,806$ \\
\hline 12 & Фарш із м'яса перепілок & $0,604 \pm 0,001$ & $0,813 \pm 0,004$ & $>0,814$ \\
\hline 13 & Фарш із м'яса гусей & $1,289 \pm 0,007$ & $1,392 \pm 0,023$ & $>1,393$ \\
\hline 14 & Фарш із м'яса качок свійських & $1,090 \pm 0,005$ & $1,222 \pm 0,006$ & $>1,223$ \\
\hline 15 & Фарш із м'яса качок мулард & $0,857 \pm 0,007$ & $1,022 \pm 0,020$ & $>1,023$ \\
\hline
\end{tabular}


Проведеними дослідженнями визначено, що найвища оптична густина свіжого та сумнівної свіжості м'ясного фаршу становила у фарші із конини $-1,302 \pm 0,004$ Б та $1,413 \pm 0,005$, із яловичини - відповідно $1,262 \pm 0,001$ та $1,320 \pm 0,007$ Б, із

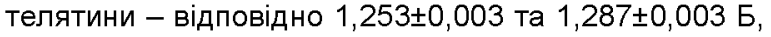
а найнижча відповідно до ступенів свіжості - у фарші із м'яса індиків - 0,504 $\pm 0,001$ Б та $0,695 \pm 0,005$ Б; у м'яса курей (філе грудки) -

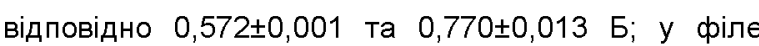
курей бройлерів («Наша Ряба») - відповідно $0,604 \pm 0,001$ та 0,805 $\pm 0,004$ Б.

Визначили оптичну густину інтенсивності забарвлення витяжки із м'ясних фраршів з реактивом Неслера різних ступеней свіжості на 25 пробах, що реалізуються у торгівельній мережі. Результати досліджень наведені в таблиці 5.

Таблиця 5

Показники оптичної густини інтенсивності забарвлення витяжки 3 м'ясних фаршів 3 реактивом Неслера різних ступеней свіжості фотометричним методом, що реалізуються у торгівельній мережі, $\mathrm{M} \pm \mathrm{n}, \mathrm{n}=\mathbf{2 5}$

\begin{tabular}{|c|c|c|c|c|}
\hline \multirow[t]{3}{*}{ № $\Pi / n$} & \multirow[b]{3}{*}{$\begin{array}{l}\text { Вид м'ясних форанів та кількість проб, } \\
\qquad n=5\end{array}$} & \multirow{2}{*}{\multicolumn{3}{|c|}{$\begin{array}{c}\text { Показники оптичної густини інтенсивності забарвлення } \\
\text { витяжки з м'ясних фрариів з реактивом Неслера, у Белах (Б) } \\
\text { Ступені свіжості м'ясних фрариів }\end{array}$}} \\
\hline & & & & \\
\hline & & $\begin{array}{c}\text { свіжі } \\
\text { (оливково-жовтий } \\
\text { колір) }\end{array}$ & $\begin{array}{c}\text { сумнівної свіжості } \\
\text { (інтенсивний жовтий } \\
\text { колір) }\end{array}$ & $\begin{array}{c}\text { несвіжі } \\
\text { (жовто- } \\
\text { помаранчевий } \\
\text { колір) } \\
\end{array}$ \\
\hline$\overline{1}$ & Фарш свинний заморожений (у тубі) & $0,849 \pm 0,001$ & $0,984 \pm 0,004$ & $>0,985$ \\
\hline 2 & $\begin{array}{l}\text { Фарш «Домашній» із свинини та } \\
\text { яловичини }\end{array}$ & $0,822 \pm 0,001$ & $1,003 \pm 0,006$ & $>1,004$ \\
\hline 3 & $\begin{array}{l}\text { Фарш «Котлетний» із свинини та } \\
\text { яловичини з додаванням сала }\end{array}$ & $0,947 \pm 0,001$ & $1,213 \pm 0,003$ & $>1,214$ \\
\hline 4 & $\begin{array}{l}\text { Фарш «Напівжирний» із свинини з } \\
\text { додаванням сала }\end{array}$ & $0,820 \pm 0,001$ & $1,111 \pm 0,005$ & $>1,112$ \\
\hline 5 & Фарш «Курячий» & $1,109 \pm 0,001$ & $1,331 \pm 0,050$ & $>1,332$ \\
\hline
\end{tabular}

Проведеними дослідженнями визначено, що найвища оптична густина із витяжки свіжого та сумнівної свіжості м'ясного фаршу становила у

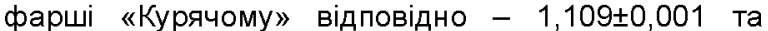
$1,331 \pm 0,050$ Б; «Котлетному" відповідно -

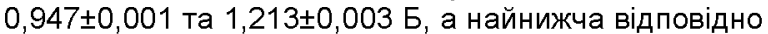
- у фарші «Домашньому» - 0,822 $\pm 0,001$ та $1,003 \pm 0,006$ Б. Ці дані були стабільними та достовірними у 99,9\%, отже ці показники можна використовувати для встановлення ступеня свіжості м'ясних фаршів, що реалізуються у торгівельній мережі поряд із загальноприйнятими методами.

Отримані дані по показникам різних ступенів свіжості м'ясної сировини були стабільними та достовірними у 99,9\%. Також більш достовірні дані - у 99,2-99,7\% були отримані в порівнянні до результатів досліджень мікроскопічного методу м'ясних фраршів та у 99,1-99,9 \% до результатів досліджень визначення вмісту аміно-аміачного азоту у м'ясних фаршах. Отже ці показники можна використовувати для встановлення ступеня свіжості м'ясних фаршів, вироблених із різних видів м'яса забійних тварин.

Розроблений фотометричний метод має перевагу перед існуючими методами визначення якості та безпечності м'ясних фраршів в тому, що за інтенсивністю забарвлення витяжки з м'ясних фаршів та реактиву Неслера можна отримати результати, які мають конкретне, достовірне кількісне значення щцдо встановлення ступеня свіжості м'ясних фаршів, виготовлених від різних видів м'яса тварин та птиці, які виготовляються із м'яса забійних тварин і реалізуються у торгівельній мережі.

\section{Висновки}

1. М'ясна сировина за загальноприйнятими методами та розробленим експресним фотометричним методом відповідала свіжому ступеню, крім фаршу «Курячого», що реалізувався у торгівельній мережі - кількість мікроорганізмів перевищували нормативи і становила $11 \pm 1$ та реакція з міді сульфатом була сумнівної свіжості. За дослідження визначення вмісту сірководню та аміаку - відмічалася негативна реакція у всіх досліджуваних пробам м'ясної сировини, крім фаршу «Курячого», у якому відмічалася сумнівна реакція.

2. Достовірність розробленого експресного фотометричного методу встановлення ступеня свіжості м'ясної сировини за визначення оптичної густини інтенсивності забарвлення м'ясо-водної витяжки внаслідок накопичення в м'ясі аміаку та солей амонію, який реагує із реактивом Неслера, утворюючи сполуку від оливково-жовтого до жовтопомаранчевий кольору, - становила 99,9 \%. Даний метод пропонується використовувати в комплексі з іншими методами для встановлення якості та безпечності даної м'ясної сировини.

3. Найвища оптична густина свіжого та сумнівної свіжості м'ясного фаршу становила у

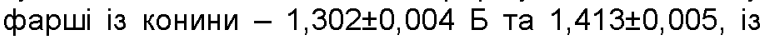
яловичини - відповідно $1,262 \pm 0,001$ та $1,320 \pm 0,007$ Б, із телятини - відповідно $1,253 \pm 0,003$ та $1,287 \pm 0,003$ Б, а найнижча відповідно до ступенів

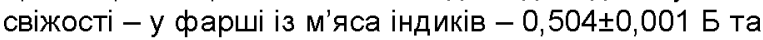
0,695 $\pm 0,005$ Б; у м'яса курей (філе грудки) -

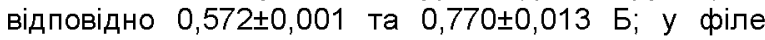
курей бройлерів («Наша Ряба») - відповідно $0,604 \pm 0,001$ та 0,805 $\pm 0,004$ Б.

4. Найвища оптична густина із витяжки свіжого та сумнівної свіжості м'ясного фаршу становила у фрарші «Курячому» відповідно - 
$1,109 \pm 0,001$ та $1,331 \pm 0,050$ Б; «Котлетному» відповідно - 0,947 $\pm 0,001$ та $1,213 \pm 0,003$ Б, а найнижча відповідно - у фарші «Домашньому» $0,822 \pm 0,001$ та $1,003 \pm 0,006$ Б
Перспективи подальиих Провести бактеріологічні та хімічні випробування досліджуваних видів м'ясної сировини.

\title{
References
}

Bogatko, N. M., Bukalova, N. V., Sakhnyuk, V. V., \& Bumblebee, V. I. (2016). Features of introduction of the HACCP system at meat, milk and fish processing enterprises of Ukraine. Belaya Tserkov: Belotserkivdruk.

Gvozdinskaya, A. V. (2017). Current state and bases of the tendency of development of the market of meat semi-finished products. Collection of sciences. Works of VI All-Ukrainian Sciences. -Prekt. conf. "Actual problems of effective social and economic development of Ukraine: search for young people" of Vinnytsia TEl and Kyiv TEU, 36, 330336

Chernorotov, O. G. (2016). Analysis of the market for livestock and meat products and meat products of Ukraine. Meat technologies, $7,25-30$

Bogatko, N. M. (2017). General principles for the introduction of traceability system in feed and food chains. Collection of sciences. works of the Kharkiv State Veterinary Academy. Problems of zoinengineering and veterinary medicine, 35(1), Part 2 "Veterinary Sciences", 34-37.

Regulation (EC) No 178/2002 of the European Parliament and of the Council of 28 January 2002 laying down the general principles and requirements of food law, establishing the European Food Safety Authority and laying down procedures in matters of safety food products.

Zasekin, D. A. (2011). Physico-chemical and biochemical bases of meat processing: a manual. Kyiv: NVP INTERSERVICE.

Bogatko, N. M., Yatsenko, I. V., Dudus, T. V., \& Bukalova, N. V. (2017). Identification of food risks from livestock to table in the context of the concept of "Single Health". Collection of abstracts of the International scientific-practical conference "Epizootology, health and welfare of animals. Challenges of the Modern "(September 12, 2017). Kyiv, Scientific and Methodological Center for Information and Analytical Support of the Activities of Higher Educational Institutions "Agro-Education", 4-6.

Desker, K. D., \& Xu, Z. I. (2009). Minimizing rancidity in muscle food. Food Technology, 53 (9), 47-53.

GOST 23392-2016. Meat. Methods of chemical and microscopic analysis of freshness. Moscow, 2017. $-8 p$

Bogatko, N. M, Nazarenko, L. V., Vlasenko, V. V. and others (2012). Biochemical and microscopic examination of meat and meat products for the determination of their veterinary and sanitary assessment: methodical recommendations. Belaya Tserkov.

Method of determining the degree of freshness of meat minced meat by photometric method: patent 128239 Ukraine: MPK51 G01N 33/12, G01N 1/28, G01N 21/79. No. 2018 022774; stated. March 19, 2013; has published 09.10.2018, Byul. No. 17.

\section{CONFORMITY OF PEA GRAIN THAT IS RETAILED TO REQUIREMENTS OF THE NATIONAL STANDARD}

\author{
M. M. Bondarevskyy, R. V. Severyn, A. M. Bohatyriova, R. O. Kryvorotko \\ Kharkiv State Zooveterinary Academy, Kharkiv, Ukraine \\ Academichna str., 1, Mala Danylivka, Dergachi district, Kharkiv region, Ukraine, 62341 \\ E-mail: alexbogatyrev1@gmail.com
}

The data on the conformity of the quality of the samples of pea grain that is retailed to the requirements of the national standard have been given in the article.

The prepacked samples of pea grain that is retailed in the trade market of Kharkiv have been investigated.

The study of the values of pea grain quality has been conducted with the use of organoleptic and laboratory methods. The materials for the investigation were the samples of pea grain that were prepacked in the plant.

Studying trademarking special attention was paid to the application of paint, printing type, the reliability of the given information.

The state standard of Ukraine (DSTU 7701:2015) was the criteria for the evaluation of the quality parameters. During the investigation it has been found that the most part of the indices was in conformity with the requirements of the normative documents

The study of the trademarking has shown that all the producers put the necessary information in accordance with the requirements. The parameters of color, smell and taste were in accordance with the national standards. Such parameters as humidity, infections, defects from pests and the presence of metal and magnetic inclusions were assessed by the laboratory investigation of pea grain quality.

Some deflections were revealed in the parameters of humidity and the presence of metal and magnetic inclusions in the samples of the trade mark "Sto pudov". The samples of the trademarks "Kazan-ok" and "Rozumnyi vybir" were in accordance with the requirements of the normative documents.

Key words: pea grain, quality, compliance with national standard. 